\title{
Erratum to: The influence of the earthworm Lampito mauritii (Kinberg) on the activity of selected soil enzymes in cadmium-amended soil
}

\author{
S. Sivakumar • D. Prabha $\cdot$ S. Barathi $\cdot$ \\ D. Nityanandi • C. V. Subbhuraam • T. Lakshmipriya • \\ Seralathan Kamala-Kannan • S. H. Jang • P. I. Yi
}

Published online: 31 August 2016

(C) Springer International Publishing Switzerland 2016

Erratum to: Environ Monit Assess (March 2015)

187, Issue 3:74

DOI 10.1007/s10661-014-4253-0

The original version of this article unfortunately contained a mistake in the acknowledgement section.

Acknowledgement should be corrected as follows.

This work was supported by Pusan National University Research Grant, 2013 by providing the necessary facilities to the author S. Sivakumar for manuscript preparation.

The online version of the original article can be found at http:10.1007/s10661-014-4253-0.

S. Sivakumar $(\bowtie) \cdot$ S. H. Jang $\cdot$ P. I. Yi

Department of Bioenvironmental Energy, College of Natural Resource and Life Science, Pusan National University,

Miryang 627-706, South Korea

e-mail: ssivaphd@yahoo.com

D. Prabha $\cdot$ S. Barathi $\cdot$ D. Nityanandi $\cdot$ C. V. Subbhuraam Department of Environmental Sciences, Bharathiar University, Coimbatore 641046, India

T. Lakshmipriya

Department of Biotechnology, Government College of

Technology, Coimbatore 641013, India

S. Kamala-Kannan

Division of Biotechnology, Advanced Institute of Environment and Bioscience, College of Environmental and Bioresource

Sciences, Chonbuk National University, Iksan, South Korea 